\title{
Genetically engineered fusion of allergen and viral-like particle induces a more effective allergen-specific immune response than a combination of them
}

\author{
Maryam Zamani Sani ${ }^{1} \cdot$ Afshar Bargahi ${ }^{1}$ - Niloofar Momenzadeh ${ }^{2} \cdot$ Parva Dehghani $^{2} \cdot$ Maryam Vakili Moghadam $^{3} \cdot$ \\ Soheila June Maleki ${ }^{4}$ - Iraj Nabipour ${ }^{2}$. Afshin Shirkani ${ }^{5}$ - Javad Akhtari ${ }^{6}$ - Khashayar Hesamizadeh ${ }^{7}$. Sahel Heidari ${ }^{3}$. \\ Fatemeh Omrani ${ }^{2} \cdot$ Samad Akbarzadeh $^{1} \cdot$ Mohsen Mohammadi $^{2}$ (D
}

Received: 28 May 2020 / Revised: 31 October 2020 / Accepted: 9 November 2020 / Published online: 20 November 2020

(C) Springer-Verlag GmbH Germany, part of Springer Nature 2020

\begin{abstract}
Chimeric virus-like particles (VLPs) were developed as a candidate for allergen-specific immunotherapy. In this study, hepatitis B core antigen $(\mathrm{HBcAg})$ that genetically fused to Chenopodium album polcalcin (Che a 3)-derived peptide was expressed in E. coli BL21, purified, and VLP formation was evaluated using native agarose gel electrophoresis (NAGE) and transmission electron microscopy (TEM). Chimeric HBc VLPs were characterized in terms of their reactivity to IgE, the induction of blocking IgG and allergen-specific IgE, basophil-activating capacity, and Th1-type immune responses. Results from IgE reactivity and basophil activation test showed that chimeric HBc VLPs lack IgE-binding capacity and basophil degranulation activity. Although chimeric HBc VLPs induced the highest level of efficient polcalcin-specific IgG antibody in comparison to those induced by recombinant Che a 3 (rChe a 3) mixed either with HBc VLPs or alum, they triggered the lowest level of polcalcin-specific IgE in mice following immunization. Furthermore, in comparison to the other antigens, chimeric HBc VLPs produced a polcalcinspecific Th1 cell response. Taken together, genetically fusion of allergen derivatives to HBc VLPs, in comparison to a mix of them, may be a more effective way to induce appropriate immune responses in allergen-specific immunotherapy.
\end{abstract}

\section{Key points}

- The insertion of allergen-derived peptide into major insertion region (MIR) of hepatitis B virus core (HBc) antigen resulted in nanoparticles displaying allergen-derived peptide upon its expression in prokaryotic host.

- The resultant VLPS (chimeric HBc VLPS) did not exhibit IgE reactivity with allergic patients' sera and were not able to degranulate basophils.

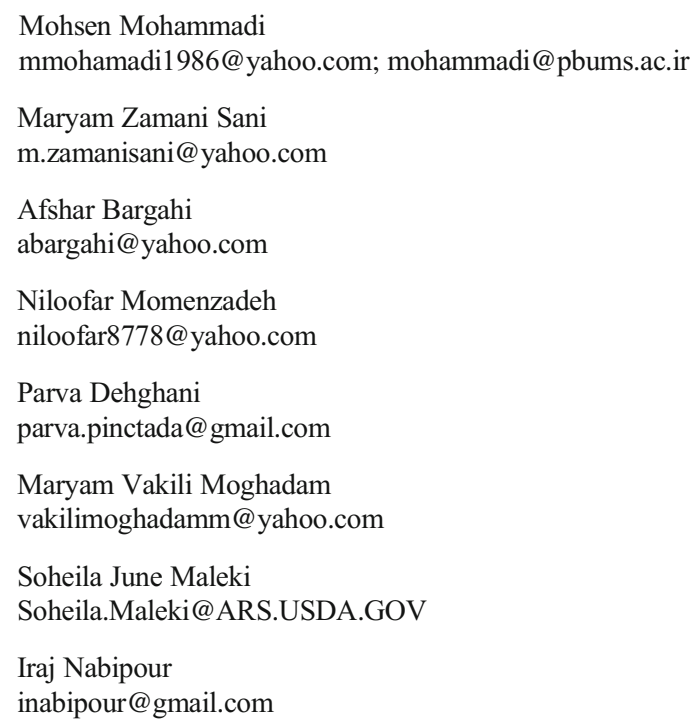

\author{
Afshin Shirkani \\ shirkani.afshin@yahoo.com \\ Javad Akhtari \\ javad.akhtari@gmail.com \\ Khashayar Hesamizadeh \\ kh.hesamizadeh@gmail.com \\ Sahel Heidari \\ heidari_sahe169@yahoo.com \\ Fatemeh Omrani \\ f.omrani58@yahoo.com \\ Samad Akbarzadeh \\ Smdakbarzadeh@yahoo.com
}

Extended author information available on the last page of the article 
- Chimeric HBC VLPs dramatically improved protective IgG antibody response compared with those induced by allergen mixed either with $H B C$ VLPS or alum.

- Chimeric HBC VLPs induced Th1 responses that were counterparts of Th2 responses (allergic).

- Chimeric HBC VLPs increased IgG2a/IgG1 ratio and the level of IFN- $\gamma$ compared to those induced by allergen mixed with either $H B C$ VLPS or alum.

Keywords Virus-like particle $\cdot$ Chimeric viral-like particle $\cdot$ Chenopodium album polcalcin $\cdot$ Vaccine design

\section{Introduction}

Type I allergy as a health problem affects up to $20-30 \%$ of the population in industrialized countries (Ghasemi et al. 2020). Allergen-specific immunotherapy (AIT), that includes the continuous oral (Pajno et al. 2014), sublingual, or subcutaneous administration of allergenic food or extract, is known as the only disease-modifying treatment of IgE-mediated allergies (Komlósi et al. 2020; Narisety and Keet 2012). The mechanism of successful AIT has not been fully elucidated. Nevertheless, a shift from Th2 toward Th1 responses or the engagement of regulatory $\mathrm{T}$ (Treg) cells, in order to reduce the recruitment of key cells in the progression of allergic disorders (e.g., basophils and mast cells), are known hallmark indicators of successful AIT (Ai et al. 2015; Ren et al. 2014). However, the efficacy and broad applicability of AIT is limited due to the disadvantages, such as time-consuming, costly physician's visits, the requirement for numerous and frequent injections, (Hedlin et al. 1991; Winther et al. 2006), low response efficiency, the potential for life-threatening (anaphylactic) reactions, and new sensitizations to non-allergenic proteins present in the extract (Burks et al. 2013; Valenta 2002). The identification and characterization of the disease-causing allergens by immunoblotting and molecular cloning techniques can lessen the variation of the quality and quantity of desired or undesired allergens in crude extracts and AIT-immediate side effects (Oliveira et al. 2010). Furthermore, manipulating the amino acid sequence of allergens to generate hypoallergens can reduce IgE-mediated side effects such as anaphylaxis shock (Ai et al. 2015). It has been established that blocking IgG antibodies (e.g., IgG4) prevents IgE binding to the allergen; thus applying hypoallergenic allergen derivatives in AIT, instead of intact allergens, can alleviate allergic symptoms (Bannon et al. 2001; Linhart and Valenta 2005; Valenta and Kraft 2002). In this way, utilization of efficient delivery platforms such as virus-like particles (VLPs) may be an effective strategy to increase the allergen-specific immunotherapy (AIT) efficacy, meanwhile, decrease the time course and cost of the treatment and the number of injections, by improving humoral immune response and establishing a balance between Th1 and Th2 response (Curin et al. 2018; Swoboda et al. 2002; Valenta and Kraft 2002).
Virus-like particles are an excellent and attractive platform for epitope presentation that induces robust immunogenic responses due to their multivalent, highly repetitive structure (Mohan et al. 2017; Wang et al. 2012). Hepatitis B core antigen $(\mathrm{HBcAg})$ can self-assemble into highly immunogenic VLP particles when expressed in prokaryotic host expression systems, and exogenous peptide can locate at the tips of surface spike of HBc VLP expressed in bacteria when inserted into the major insertion region (MIR) of HBc VLP. The major insertion region is the most immunodominant site exposed on the surface of HBc VLPs. The insertion of foreign antigen into this site via genetic fusion can generate recombinant chimeric $\mathrm{HBc}$ particles, decorated with the inserted antigen, that can preferably induce a strong antibody response against the inserted antigen (Guo et al. 2019; Peyret et al. 2015). The encapsidation of nucleic acid compounds (DNA, RNA) from bacterial host into the VLP during VLP formation process inside bacteria induces TLR7/8- and 9-mediated interferonalpha (IFN- $\alpha$ ) secretion from dendritic cells that suppress Th2 responses (Huber et al. 2010; Mohsen et al. 2020), while skewing the immune response toward a Th1 response, which is a desired response in successful AIT (Anzaghe et al. 2018; Sominskaya et al. 2013; Storni et al. 2020). Researchers have applied VLPs in different ways for allergy treatment. Some of them have used CpG-encapsulated VLP either alone or mixed with allergen extract in order to induce general Th1 response in allergic diseases (Beeh et al. 2013; Klimek et al. 2011; Senti et al. 2009), or chemically conjugated it to allergen-derived peptide to produce allergen-specific IgG antibodies (Kündig et al. 2006). However, further evaluation is needed on whether mixing VLP with allergen or allergen derivatives is sufficient for inducing the desired immune response or if conjugation of VLPs to allergen is a better approach. In the current study, chimeric HBc VLP (displaying a hypoallergenic allergenderived peptide) was produced, and its ability to induce the desired immune response was then compared to those induced by allergen mixed with either alum or HBc VLPs. To this aim, the Chenopodium album polcalcin (Che a 3) attributed to two EF-hand allergens (Verdino et al. 2008) was used as an allergen model for the following reasons that it is a potent allergenic protein, has high cross-reactivity with pollens of various plants (trees, bushes, grasses, weeds, and flowering plants) 
(Ledesma et al. 2006; Tinghino et al. 2002), and is the most commonly recognized allergen by chenopod pollensensitized patients (Barderas et al. 2003; Hauser et al. 2010; Verdino et al. 2008). Therefore, HBc VLP, which is the most common and preferred VLP to display antigen through genetic fusion (Oliveira et al. 2005; Pumpens et al. 1995; Schödel et al. 1996), was used to generate chimeric HBc VLPs displaying a hypoallergenic allergen-derived peptide.

Due to the low insertion capacity of MIR-HBc for foreign antigen, it was impossible to insert full-length of Che a 3 into MIR (Pumpens and Grens 2001). Hence, according to the study of Westritschnig, K et al. (Westritschnig et al. 2004), the C-terminal half segment of Che a 3 (called as C. Che a 3) was selected as hypoallergenic Che a 3 derivative and was genetically fused to MIR on the $\mathrm{HBcAg}$ to produce VLP presenting C. Che a 3 (chimeric HBc VLP). Evaluation of immune responses in immunized mice revealed that chimeric $\mathrm{HBc}$ VLP was more potent than the other combination treatments (allergen + HBc VLP/alum) to drive the immune responses (i.e., allergen-specific IgG, Th1 response) in favor of allergy immunotherapy (Smarr et al. 2013).

\section{Materials and methods}

\section{Plasmid construction and expression of chimeric $\mathrm{HBC}$ VLP}

Recombinant $\mathrm{CoHBc}$ plasmid containing $\mathrm{HBc}$ antigen (MW $\sim 20.9 \mathrm{kDa}$ ) coding nucleotide sequence from hepatitis B virus (HBV320 genome, genotype D1, subtype ayw2, GenBank accession number X02496) was kindly gifted from professor David Rowlands (University of Leeds). This construct contains restriction sites (EcoRI and Nhe I restriction enzymes) that were placed in the MIR loop (S. data 1). Gene-encoding C-terminal half (aa: 45-86) of Che a 3 (accession No: AY082338.1) plus GGGGS linker at both ends with recognition site of restriction enzymes EcoRI/NheI at the ${ }^{\prime}$ ' and $5^{\prime}$ end (MW $\sim 5.72 \mathrm{kDa}$ ) was synthesized (Pepmic Co., China). Then, the $\mathrm{CoHBc}$ plasmid and synthesized gene were digested with EcoR1/Nhel; subsequently, the digested gene was inserted into MIR sit of $\mathrm{HBc}$ to construct chimeric $\mathrm{HBc}$ (MW $\sim 26.62 \mathrm{kDa}$ ) (accession number: MT625678) (Fig. $1 \mathrm{a}, \mathrm{d})$. The accuracy of nucleotide sequence of resultant recombinant plasmid was confirmed through restriction enzyme mapping and Sanger sequencing method. The structure of chimeric $\mathrm{HBc}$ protein was predicted via submitting its amino acid sequence in the ITASSER server (https://zhanglab.ccmb. med.umich.edu/I-TASSER/) (Fig. 1d).

To perform the cloning of chimeric $\mathrm{HBc}$ plasmid, E. coli TOP10 cells (Invitrogen) were transformed by chimeric HBc plasmid, and a positive clone was selected on Luria-Bertani (LB) agar containing $50 \mu \mathrm{g} / \mathrm{ml}$ kanamycin. For expression, the $E$. coli B121 strain (DE3) (Invitrogen) was transformed by chimeric $\mathrm{HBc}$ plasmid or $\mathrm{CoHBc}$ plasmid, and expression was induced by adding IPTG (Sigma-Aldrich, Germany) to the final concentration of $0.2 \mathrm{mmol} / 1$ for $20 \mathrm{~h}$ at $18^{\circ} \mathrm{C}$. For evaluation of protein expression, the bacterial cells (optical density at $600 \mathrm{~nm} \sim 6-7$ ) were collected and lysed in $200 \mu \mathrm{l}$ of Laemmli buffer, and $15 \mu$ l of the lysate was then employed in SDS-PAGE.

\section{Purification of chimeric HBc VLP and HBc VLPs}

Overnight $E$. coli bacterial culture at $18^{\circ} \mathrm{C}$ (transformed $E$. coli cells) was centrifuged at $5000 \mathrm{rpm}$ for $20 \mathrm{~min}$ at $4{ }^{\circ} \mathrm{C}$ to collect the bacterial cells. After this, the cells were washed three times with PBS ( $\mathrm{pH} 7)$ to remove any proteolytic agent, and then resuspended in lysis buffer $(50 \mathrm{mM}$ Tris- $\mathrm{HCl}, \mathrm{pH} 8,150 \mathrm{mM}$ $\mathrm{NaCl}, 5 \mathrm{mM}$ DTT, $0.1 \%$ Triton X-100, 10 mM EDTA, $0.5 \mathrm{mM}$ urea, $1 \mathrm{mg} / \mathrm{ml}$ lysozyme, $1 \times$ protease inhibitor cocktail (Roche)). Purification of protein was performed by incubation of the cells ( $4 \mathrm{~g}$ ) in $16 \mathrm{ml}$ of lysis buffer on ice for $30 \mathrm{~min}$, and then the cells were lysed six times by ultrasonication with $40 \%$ amplitude with $20 \mathrm{~s}$ on and $50 \mathrm{~s}$ off on ice. The lysate became transparent by centrifugation at $12,000 \mathrm{rpm}$ for $30 \mathrm{~min}$ at $4{ }^{\circ} \mathrm{C}$. Solid ammonium sulfate was then added to the supernatant until it reached $35 \%$ saturation and incubated overnight at 4 ${ }^{\circ} \mathrm{C}$. The next day, suspension was centrifuged at 10,000 rpm for $30 \mathrm{~min}$ at $4{ }^{\circ} \mathrm{C}$. The precipitated protein was dissolved in $20 \mathrm{mM}$ Tris-Hcl buffer $\mathrm{pH} 8$, containing $150 \mathrm{mM} \mathrm{NaCl}$, 10 mM EDTA, $0.1 \%$ Triton X-100 (Sigma-Aldrich, Germany), and $1 \times$ protease inhibitor cocktail (Sigma-Aldrich, Germany). It was then heated at $55^{\circ} \mathrm{C}$ for $30 \mathrm{~min}$, and contaminating proteins were removed by centrifugation at $9000 \mathrm{rpm}$ for $15 \mathrm{~min}$ at $4{ }^{\circ} \mathrm{C}$. Then VLPs were further purified by conventional anion exchange chromatography. To this end, the supernatant was first dialyzed against binding buffer $(20 \mathrm{mM}$ Tris-Hcl, pH 8, $150 \mathrm{mM} \mathrm{NaCl}, 0.1 \%$ Triton X-100, $1 \times$ protease inhibitor cocktail, and $0.5 \mathrm{M}$ urea (Merck, UK). Proteins were fractioned with the AKTA Prime Plus FPLC system (GE Healthcare) equipped with a column packed with diethylaminoethyl (DEAE) column (GE Healthcare, Germany) as the anion exchange matrix. Proteins were eluted by a linear gradient mixture of binding buffer $(20 \mathrm{mM}$ Tris- $\mathrm{HCl}$ $\mathrm{pH}$ 8.6) supplemented with $1 \mathrm{M} \mathrm{NaCl}$ solution as described elsewhere (Mohamadi et al. 2016) and VLPs were precipitated by adding ammonium sulfate to reach a final saturation of $50 \%$ and then the precipitated VLPs were dissolve and dialyzed by a working buffer $(50 \mathrm{mM}$ Tris- $\mathrm{Hcl}, \mathrm{pH} 8$ and $150 \mathrm{mM} \mathrm{NaCl}$, $2 \mathrm{mM}$ DTT, $1 \times$ protease inhibitor cocktail).

\section{HBC VLP formation analysis}

Native agarose gel electrophoresis (NAGE) as a simple method was used to evaluate VLP formation through the presence 


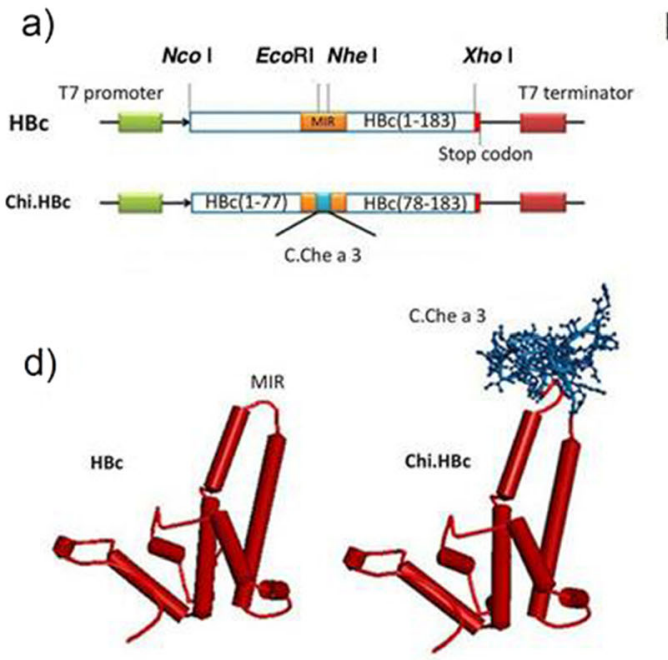

Fig. 1 Schematic representation of construct plasmid, production, and confirmation of VLP formation. a Map of $\mathrm{HBc}$ and chimeric $\mathrm{HBc}$ (Chi.HBc) plasmids, Che a 3 was inserted in Eco R1/Nhe1 enzyme cleavage sites on the major insertion region (MIR) on the $\mathrm{HBcAg}$ protein. b Analysis of the expression and purity of recombinant proteins by SDS-PAGE. Line A: total cell lysates of chimeric HBc-expressing BL-21 E.coli bacteria; line B: chimeric HBc VLPs $(26.62 \mathrm{kDa})$ were purified by anion exchange chromatography; line C: total cell lysates of HBc-expressing BL-21 E. coli bacteria; line D: HBc VLPs (20.9 kDa)

of the same band of protein and nucleic acids on native agarose gel electrophoresis (NAGE). For NAGE, $0.7 \%$ UltraPure agarose (Invitrogen, USA) in TAE buffer ( $40 \mathrm{mM}$ Tris, $20 \mathrm{mM}$ acetic acid, $1 \mathrm{mM}$ EDTA) was used. The purified VLPs $(1.5 \mathrm{mg} / \mathrm{ml})$ were loaded on a $0.7 \%$ agarose gel, and electrophoresis was performed for $40 \mathrm{~min}$ at $100 \mathrm{~V}$. Following the staining of the gel with EtBr solution (TAE buffer +1 $\mu \mathrm{g} / \mathrm{ml} \mathrm{EtBr}$ ), the gel was stained with Coomassie Blue G-250 $(60 \mu \mathrm{g} / \mathrm{ml}$ of Coomassie Blue G-250 in $10 \%$ acetic acid). After early detection of VLP formation by NAGE, electron microscopy was employed in order to direct observation of VLP particles. For this purpose, VLP containing Tris buffer was adsorbed onto carbon formvar-coated copper grids and negatively stained with a $1 \%$ uranyl acetate aqueous solution; then grids were evaluated with a ZEISS EM900 transmission electron microscope.

\section{Synthesis and characterization of C-terminal half of Che a 3 peptide (C. Che a 3 peptide)}

The C-terminal half of Che a 3 (C. Che a 3 peptide) was synthesized using a solid-phase synthesis method using $N$-(9-fluorenyl) methoxycarbonyl (Fmoc) chemistry (Pepmic, Suzhou, China). These peptides were then purified by RP-HPLC using SHIMADZU Inertsil ODS-SP $(4.6 \times$ $250 \mathrm{~mm} \times 5 \mu \mathrm{m}$ ) column, which was eluted by a $0-100 \%$ $\mathrm{H}_{2} \mathrm{O}$ /acetonitrile gradient containing $0.1 \%$ trifluoroacetic acid (TFA) for $30 \mathrm{~min}$. Homogeneity of the peptide was assayed by analytical high-performance liquid chromatography using

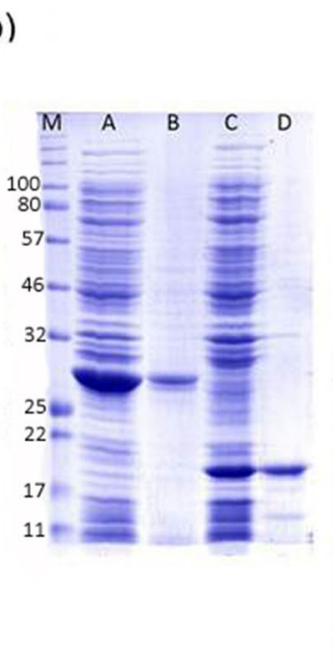

c)

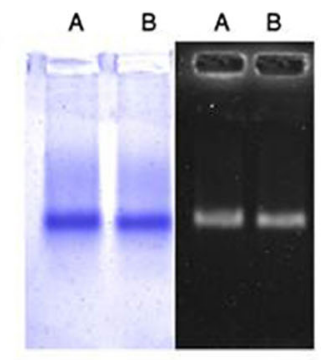

e)

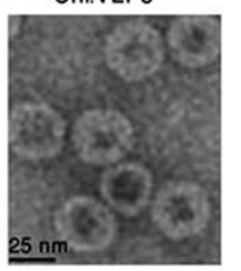

HBc VLPS

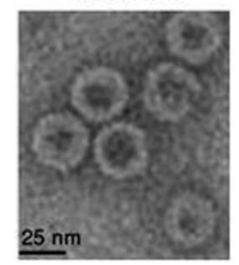

were purified by anion exchange chromatography; and line M: low molecular weight protein marker (LMWM, kDa). c NAGE analysis of purified chimeric $\mathrm{HBc}$ and $\mathrm{HBc}$ VLPs, NAGE analysis of purified HBc, and chimeric HBc VLP by coomassie (left) and ethidium bromide (right) staining. Lines A and B represent chimeric HBc VLPs and HBc VLP, respectively. d Representation of protein structure of $\mathrm{HBc}$ (left), chimeric $\mathrm{HBc}$ (right). e Electron microscopy confirmed VLP formation for $\mathrm{HBc}$ and chimeric HBc VLPs

Inertsil ODS-SP $(4.6 \times 250 \mathrm{~mm} \times 5 \mu \mathrm{m})$ column that demonstrated a $90 \%$ purity. The atomic mass of the purified peptides was determined by mass spectrometry (MS).

\section{Allergic patients}

Sera from 9 males and 6 females (with mean ages 30.13 years old) with a clinical history of respiratory allergy, positive skin prick test (SPT) for C. album, and positive result with commercial enzyme allergosorbent test (EAST; Dr. Fuke, Germany) were collected. Afterward, the sera were investigated for the presence of Che a 3-specific IgE by recombinant Che a 3 (rChe a 3)-based ELISA (Table S1) to choose rChe a 3 -sensitized patients' sera. The rChe a 3 protein is the recombinant form of full-length rChe a 3 protein expressed in E. coli $\mathrm{B}$ strain (DE3) that was kindly gifted by Dr. A. Varasteh (BuAli Research Center, Mashhad, Iran), and a full description of its production has been described elsewhere (Nouri et al. 2012). For the negative control, sera were collected from seven healthy individuals with no history of allergy and also with negative SPT for the commercial crude extract of C. album.

\section{ELISA assay for IgE reactivity of chimeric HBC VLP, rChe a 3, and C. Che a 3 peptide}

$\mathrm{IgE}$ reactivity of rChe a 3 protein, $\mathrm{C}$. Che a 3 peptide, chimeric HBC VLP, and HBc VLP were examined with rChe a 3sensitized patients' sera by ELISA method. For ELISA, plate wells were coated with $10 \mu \mathrm{g} / \mathrm{ml}$ of rChe a 3 , C. Che a 3, 
chimeric HBc VLP, or HBc VLP diluted in $0.2 \mathrm{M}$ bicarbonate buffer $\mathrm{pH} 9.0$. After overnight incubation at $4{ }^{\circ} \mathrm{C}$, the wells were washed three times with $1 \times$ phosphate-buffered saline and $0.05 \%$ Tween-20 (PBS-T) and then blocked with $1 \%$ bovine serum albumin (BSA). The blocked wells were washed three times with PBS-T, exposed to either sera from rChe a 3-sensitized patients (1:5 diluted patient sera) or to 1:5-diluted sera from healthy individuals ( $n$ : 7), and incubated for $2 \mathrm{~h}$ at $37^{\circ} \mathrm{C}$. Afterward, the wells were washed three times PBS-T and exposed to 1:2000diluted biotin-labeled anti-human IgE (Abcam, USA). Again after three times washing with PBS-T, the wells were incubated for $1 \mathrm{~h}$ with 1:30,000-diluted horseradish peroxidase (HRP)conjugated streptavidin (Sigma, MO, USA). After the addition of TMB/H2O2 chromogen/substrate (Sigma, MO, USA), the plates were incubated in the dark for $15 \mathrm{~min}$. The reaction was stopped by adding $100 \mu \mathrm{l}$ of $2 \mathrm{~N} \mathrm{H}_{2} \mathrm{SO}_{4}$ solutions. Finally, the optical density (OD) of the wells was measured at two wavelengths of 450 and $630 \mathrm{~nm}$ to remove optical interference and background signals from unwanted reactions.

\section{Basophil activation assays}

Basophil activation test was performed as previously described (Sanz et al. 2001). To this end, $15 \mathrm{ml}$ of heparinized peripheral whole blood sample was obtained from five patients with positive skin prick test (SPT) for C. album. Heparinized blood samples (from rChe 3-sensitized patients) were then centrifuged $\left(500 \mathrm{~g}\right.$ at $4^{\circ} \mathrm{C}$ ) for $10 \mathrm{~min}$ and buffy coat was collected and centrifuged $\left(500 \mathrm{~g}\right.$ at $\left.4{ }^{\circ} \mathrm{C}\right)$ for $10 \mathrm{~min}$. The supernatant was removed, and the cell pellet was dissolved in stimulation buffer $(100 \mu \mathrm{l})$ contained $2 \mathrm{ng} / \mathrm{ml}$ of interleukin 3 (IL-3) (20 mM HEPES, $133 \mathrm{mM} \mathrm{NaCl}, 5 \mathrm{mM}$ $\left.\mathrm{KCl}, 7 \mathrm{mM} \mathrm{CaCl}_{2}, 3.5 \mathrm{mM} \mathrm{MgCl}_{2}, 1 \mathrm{mg} / \mathrm{ml} \mathrm{BSA}, \mathrm{pH} 7.4\right)$. Then various dilutions $(100 \mu \mathrm{l})$ of rChe a 3, C. Che a 3, or chimeric HBc VLPs were added to the suspension and incubated at $37{ }^{\circ} \mathrm{C}$ for $20 \mathrm{~min}$. Anti-IgE mAb $(1 \mu \mathrm{g} / \mathrm{ml})$ (Immunotech, Marseille, France) and PBS (negative control) were used as positive and negative controls, respectively. Afterward, red blood cells (RBCs) were lysed with RBC lysis buffer (Abcam), centrifuged at $500 \mathrm{~g}$ for $10 \mathrm{~min}$, and washed twice with a wash buffer (PBS containing $2 \%$ FCS). The cells were dissolved in a wash buffer and incubated with PE antihuman CD63 and FITC anti-human CD193 (CCR3) antibodies (Biolegend, London, UK) at $25^{\circ} \mathrm{C}$ for $30 \mathrm{~min}$. The stained cells were evaluated using fluorescence-activated cell sorting (FACS), and the data were analyzed using the FlowJo software (version 7.6.1).

\section{Immunization of mice and assessment of rChe a 3- specific IgG response}

Female Balb/c mice (6-8 weeks of age) were purchased from Animal Laboratory, Pasture Institute of Iran. The animals were kept at a constant temperature $\left(25^{\circ} \mathrm{C}\right)$ and were fed with customary laboratory food and water. All animal procedures were conducted according to the ethics committee of Bushehr University of Medical Sciences to the "Guide for the Care and Use of Laboratory Animals" from the US National Institutes of Health (Care IoLARCo, Animals UoL, Resources NIoHDoR 1985). Seven groups of mice (five mice/group) were subcutaneously immunized on days 0,14 , and 21 with rChe a 3 protein $(25 \mu \mathrm{g})$ or C. Che a 3 peptide $(25 \mu \mathrm{g})$ that is mixed with either an equal volume $(50 \mu \mathrm{l})$ of alum $(2 \% \mathrm{w} / \mathrm{v})$ or HBc VLP $(10 \mu \mathrm{g})$, chimeric HBC VLPs $(10 \mu \mathrm{g})$, HBc VLP $(10 \mu \mathrm{g})$, and PBS. The sera of the mice were evaluated on days $0,14,21$, and 28 after the first immunization in terms of antibody response. For the measurement of rChe a 3-specific IgG response in the sera of the mice, the wells were coated with $10 \mu \mathrm{g} / \mathrm{ml}$ of rChe a 3 and incubated with a 10 -fold serial dilution of the sera of the mice (non-immunized or immunized sera). After the washing steps, the wells were developed with 1/1000-diluted goat anti-mouse IgG-HRP (Biolegend, UK) for $2 \mathrm{~h}$ at room temperature (RT). Then, the rChe a 3specific IgG response in immunized mice was calculated with $\mathrm{TMB} / \mathrm{H}_{2} \mathrm{O}_{2}$ chromogen/substrate (Sigma, MO, USA) at OD $450 / 630 \mathrm{~nm}$. The endpoint titer for each sample was determined and used to compare IgG levels between mice groups. For this purpose, cutoff titers were determined for each serum dilution by calculating the absorbance (mean +3 standard deviation) obtained from each serum dilution of preimmunized mouse. The titer endpoint for each sample was expressed as reciprocal of the highest 10-fold dilution that had an absorbance greater than the corresponding cutoff values obtained from preimmunized mice sera. ELISA was performed in triplicate for all samples.

\section{Evaluation of rChe a 3-specific IgE response in the sera of immunized mice}

Sera from immunized mice of previous experiments were investigated to determine the rChe a 3 -specific IgE response. To this end, the wells coated with rChe a $3(10 \mu \mathrm{g} / \mathrm{ml})$ were blocked with $1 \%$ BSA and incubated with a 5-fold dilution of mice sera (immunized sera) for $2 \mathrm{~h}$ at $37^{\circ} \mathrm{C}$. The wells were washed three times with PBS-T and developed with 1/500diluted goat anti-mouse IgE-HRP (Thermo Scientific, Waltham, MA, USA) for $2 \mathrm{~h}$ at RT. Then, the rChe a $3-$ specific IgE response in immunized mice sera was determined by adding $\mathrm{TMB} / \mathrm{H}_{2} \mathrm{O}_{2}$ chromogen/substrate at $450 / 630$ as described above.

\section{Inhibition of allergic patients' IgE binding to rChe a 3 by immunized mice sera}

Competitive inhibition ELISA assay was used to assess blocking allergic patients' IgE binding to rChe a 3 by sera 
from immunized mice. For ELISA inhibition, ELISA wells were coated with $10 \mu \mathrm{g} / \mathrm{ml}$ of rChe a 3, and after blocking with $1 \%$ BSA, these coated wells were incubated with 10 -fold serial dilution of mice sera from immunized mice or preimmunized mice $(1: 100 \mathrm{v} / \mathrm{v})$, and after the washing step, wells were incubated with pool sera from rChe a 3 -sensitized patients $(n: 10)$ or non-sensitized individuals $(n: 7,1: 5 \mathrm{v} / \mathrm{v})$. In the next step, wells were developed with 1:2000-diluted biotin-labeled anti-humans IgE (Abcam, USA) and then with 1:30000-diluted HRP-conjugated streptavidin (Sigma, MO, USA) for $1 \mathrm{~h}$ at RT. The inhibitory effect of sera from immunized mice on allergic patients' IgE binding to rChe a 3 was calculated by the following formula:

(OD of sample without inhibitor-OD of sample with inhibitor/OD of sample without inhibitor) $\times 100$.

\section{Determination of IgG subclasses and cytokine responses in immunized mice}

The titers of two subclasses of antibodies (IgG1/IgG2a) were examined in mice sera by ELISA. To this end, plates were coated with rChe a $3(10 \mu \mathrm{g} / \mathrm{ml})$ diluted in $0.2 \mathrm{M}$ bicarbonate buffer, $\mathrm{pH} 9.0$, and left overnight at $4{ }^{\circ} \mathrm{C}$. The coated wells were washed three times with PBS-T and blocked with $1 \%$ BSA by incubation at $37{ }^{\circ} \mathrm{C}$ for $2 \mathrm{~h}$. The blocked wells were then washed three times with PBS-T and incubated with $100 \mu \mathrm{l}$ of 1:100-diluted mice sera. After washing steps, the wells were incubated with $100 \mu$ l of diluted biotin-labeled anti-mice IgG (Mab Tech, Stockholm, Sweden), including 1:1000 anti-IgG1 or 1:250 anti-IgG2a for $2 \mathrm{~h}$ at RT. The wells were then washed again with PBS-T and incubated for $1 \mathrm{~h}$ with 1:3000-diluted HRP-conjugated streptavidin. Nonbinding HRP-conjugated streptavidin was removed by washing; $\mathrm{TMB} / \mathrm{H}_{2} \mathrm{O}_{2}$ chromogen/substrate (Sigma, MO, USA) was added to the plates and incubated in the dark for 15 $\min$. The reaction was stopped by the addition of $100 \mu$ of $2 \mathrm{~N} \mathrm{H}_{2} \mathrm{SO}_{4}$ solutions. Finally, the optical density (OD) of the wells was measured at $450 \mathrm{~nm}$. Sera, secondary antibodies, and HRP-conjugated streptavidin were diluted in 1\% BSA.

For cytokine response assay (IFN- $\gamma$ ), mouse splenocytes were isolated on day 42 and were converted to single-cell suspension in RPMI 1640 by passing through mesh with pore size $70 \mu \mathrm{m}$ under aseptic conditions. Red blood cells were removed by osmotic shock, and the cells were washed with RPMI 1640 and resuspended in medium supplemented with $10 \%$ heatinactivated fetal bovine serum (FBS) from cattle/bovine (Gibco, Fisher Scientific, UK) $100 \mathrm{IU} / \mathrm{ml}$ penicillin and 100 $\mu \mathrm{g} / \mathrm{ml}$ streptomycin. Mouse splenocytes were stimulated with rChe a $3(5 \mu \mathrm{g} / \mathrm{ml}), \mathrm{HBc}$ VLP $(5 \mu \mathrm{g} / \mathrm{ml})$, or phytohemagglutinin (PHA, $5 \mu \mathrm{g} / \mathrm{ml}$ ) as positive control $(5 \mu \mathrm{g} / \mathrm{ml})$. In addition, the wells containing mouse splenocytes were incubated with PBS as unstimulated control. After $48 \mathrm{~h}$, the supernatant of cell cultures was removed, and the cytokine level was examined with mouse
IFN- $\gamma$ ELISA set (Mouse IFN- $\gamma$ ELISA MAX MT Standard) according to the manufacturer's instructions. All materials for culture were purchased from Gibco, UK.

\section{Statistical analysis}

The obtained data were analyzed and compared using oneway ANOVA or student's unpaired $t$ test. A $p$ value of less than 0.05 was considered statistically significant. The GraphPad Prism 6 software was used to depict the charts.

\section{Results}

\section{Construction, expression, and purification of chimeric HBC VLPs and HBC VLPs}

In the present study, we constructed a hybrid containing Che a 3derived peptides (C. Che a 3 ) fused to $\mathrm{HBc}$ protein in order to compare immune responses induced by allergen-derived peptide or full-length allergen either mixed with HBc VLPs or allergenderived peptide linked to HBc VLPs. For this purpose, the encoding gene for the $\mathrm{C}$-terminal half of Che a 3 with EcoR1/ Nhe1 cleavage site at both ends and $\mathrm{CoHBc}$ plasmid were digested with EcoR1/Nhe1 enzymes, and after the ligation of C. Che a 3 into the MIR site of HBc-coding sequence, vaccine construct (chimeric $\mathrm{HBc}$ ) was created and termed chimeric $\mathrm{HBc}$ VLPs (Fig. 1a).

The recombinant protein chimeric HBc VLPs and HBc VLPs were successfully expressed in E. coli BL21 (DE3). After the preliminary confirmation of VLP formation in cell lysate by NAGE, VLPs were precipitated by ammonium sulfate from clarified supernatant, and for further purification, the suspension containing VLPs undergone anion exchange chromatography (Fig. 1b). To estimate the concentration of purified VLP materials, fractions containing VLPs were pooled and the Bradford result indicated approximately a yield of 6 and $8 \mathrm{mg} / \mathrm{L}$ culture for chimeric $\mathrm{HBc}$ VLPs and HBc VLPs.

\section{Characterization of VLPs}

The observation of a corresponding band in Coomassie and ethidium bromide staining of NAGE indicated the formation of VLP and encapsulation of nucleic acids in VLPs. Homogeneity analysis of HBc- and chimeric HBc VLPs by NAGE gel showed that some chimeric HBc particles do not run onto the NAGE under electrophoresis and stay in the wells of the gel; this can be due to the aggregation or undesirable disassembly (Fig. 1c). For direct observation and confirmation of VLP formation, a suspension containing VLPs was evaluated by negative-staining transmission electron microscopy, and VLP formation by self-assembling of monomeric 
chimeric $\mathrm{HBc}$ protein into chimeric HBc VLPs was demonstrated (Fig. 1e).

\section{C-terminal half of Che a 3 peptide (C. Che a 3 ) and chimeric HBC VLPs showed very low IgE reactivity compared to rChe a 3}

The IgE reactivities of $\mathrm{C}$. Che a 3 peptide, chimeric $\mathrm{HBc}$ VLPs, and rChe a 3 were evaluated by ELISA. ELISA data revealed a significant reduction for $\mathrm{IgE}$ reactivity of C. Che a 3 peptide and chimeric HBc VLPs (13.00- and 11.14-fold, respectively) compared with rChe a 3 , in which mean ODs for IgE reactivity of rChe a 3 was estimated as $0.78 \pm 0.15$, while for C. Che a 3 peptide and chimeric HBc VLPs were $0.06 \pm$ 0.01 and $0.07 \pm 0.01$, respectively. No significant difference was observed for IgE reactivity of $\mathrm{C}$. Che a 3 peptide or chimeric HBc VLPs in the sera from rChe a 3-sensitized patients (Fig. 2).

\section{C-terminal half of Che a 3 peptide (C. Che a 3 ) and chimeric HBC VLPs are almost unable to upregulate CD63 expression}

A basophil activation test was used to determine the allergenic properties of rChe a 3, C. Che a 3, and chimeric HBc VLPs using PBMCs from rChe a 3-sensitized patients. C. Che a 3 and chimeric $\mathrm{HBc}$ VLPs failed to upregulate CD63 expression (as the specific basophil activation marker), even at high concentrations, while rChe a 3 strongly triggers CD63 expression in a dose-dependent manner (Fig. 3).

\section{Chimeric HBc VLPs induce a rapid and robust IgG response}

The antibody response in immunized sera was assessed by indirect ELISA method. Chimeric HBc VLPs induced robust and fast rChe a 3-specific antibody response so that only 2

weeks after the first immunization, a high titer of specific $\operatorname{IgG}$ antibody was observed in comparison to those induced by other antigens. Furthermore, 4 weeks after the first immunization, rChe a 3-specific IgG antibody in mice immunized with chimeric HBc VLPs was significantly higher than that in mice immunized with the other antigens. No significant difference was observed in the antibody titer when allergen or allergenderived peptide mixed with alum or HBc VLPs. The mice immunized with HBc VLPs resembled mice immunized with PBS were not able to produce rChe a 3-specific IgG (Fig. 4).

\section{RChe a 3 mixed with alum induced the highest level of rChe a 3-specific IgE antibody in mice}

The ability of antigens to trigger rChe a 3-specific IgE antibody was evaluated in mice after the immunization. As shown in Fig. 5, rChe a 3 or C. Che a 3 mixed with alum induced a higher level of rChe a 3-specific IgE antibody in comparison mixing with $\mathrm{HBc}$ VLP. Furthermore, full-length allergen (rChe a 3), particularly in combination with alum, produced the highest level of rChe a 3-specific IgE antibody compared to the other antigens. Interestingly, mice immunized with $\mathrm{C}$. Che a 3 (when mixed with HBc VLP) or chimeric HBc VLPs produced the lowest level of rChe a 3-specific IgE antibody. Moreover, chimeric HBc VLPs produced less level of rChe a 3-specific IgE antibody compared to that produced by C. Che a 3 mixed with alum.

\section{Chimeric HBc VLPs produced the highest level of rChe a 3-specific blocking lgG antibodies}

ELISA findings revealed that in comparison to the other antigens, chimeric HBc VLPs produced IgG antibodies in mice which were able to inhibit the binding of allergic patients' IgE to rChe a 3 even in the high mouse antisera dilution, so that at $1: 10^{2}$ - to $1: 10^{6}$-fold dilution of sera, only a slight change was observed in blocking

Fig. 2 C. Che a 3, chimeric $\mathrm{HBc}$ VLP showed a highly reduced $\mathrm{IgE}$ reactivity. $\operatorname{IgE}$ reactivity of rChe a 3, C. Che a 3, and chimeric HBc VLPs were determined by ELISA. Chart represents the comparison of IgE reactivity of rChe a 3, C. Che a 3, chimeric $\mathrm{HBc}$ VLP, and HBc VLP by ELISA in sera from sensitized patients $(n: 15)$ and healthy individuals $(n: 7)$. $p$ value less than 0.05 was regarded as statistically significant. Symbol signs: *, $p \leq 0.05 ; * *, p \leq 0.01$; $* * *, p \leq 0.001 ;$ n.s: not significant
IgE-binding capacity

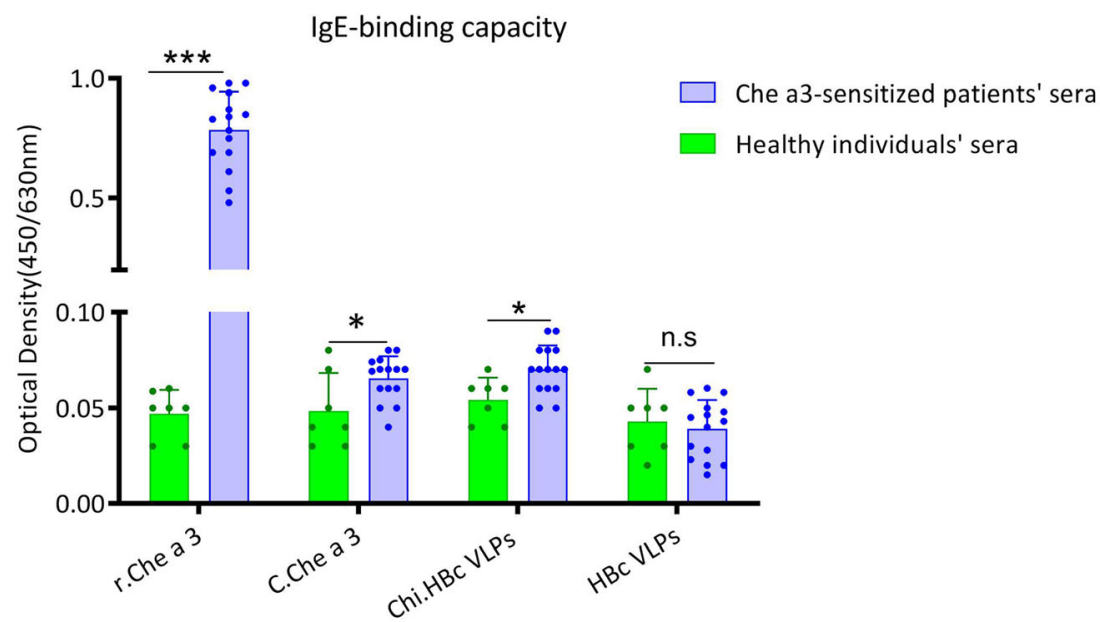


a)
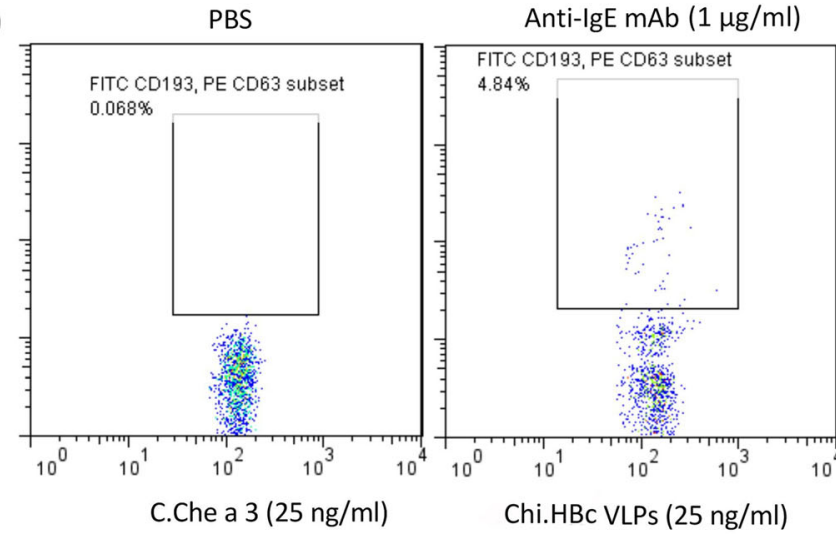

rChe a $3(25 \mathrm{ng} / \mathrm{ml})$
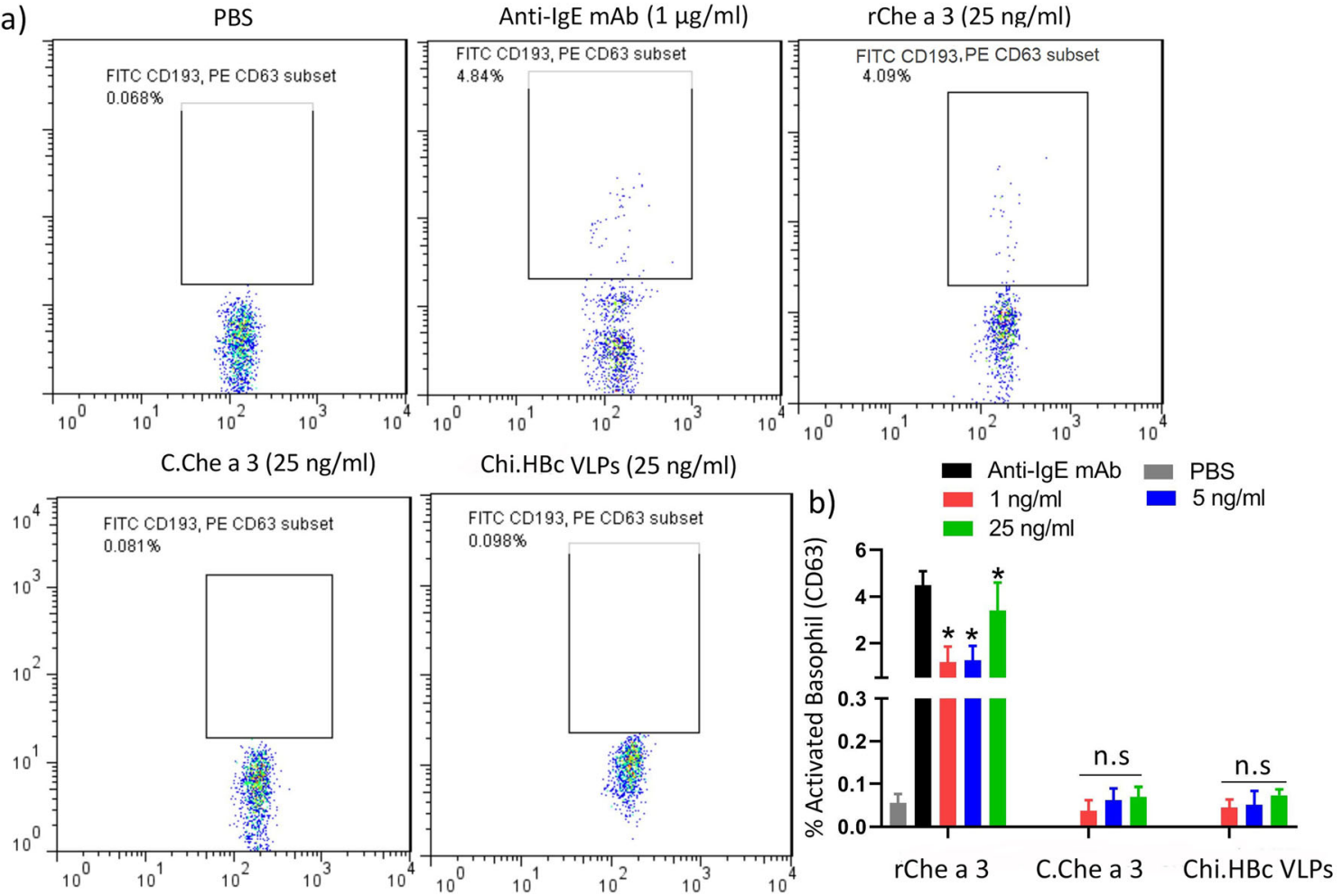

Fig. 3 Chimeric HBc VLPs fail to activate human basophil cells. Whole blood cells from rChe a 3-sensitized patients $(n: 5)$ were incubated with rChe a 3, C. Che a 3, chimeric HBc VLPs, anti-IgE, or PBS. The upregulation of CD63 (basophil activation marker) was assayed on CCR3-gated cells (basophil) using flow cytometery. a The flow chart represents one experiment out of five for each protein that showed the percentage of CCR3 (CD193), CD63 double-positive cell (activated

basophil). b The percentage of activated basophil (CCR3, CD63 double-positive cell subset) induced by each protein was calculated and expressed as mean \pm SD. The percentage of CCR3, CD63 doublepositive cells of each protein compared with that of PBS-treated whole blood cells. Symbol meaning: *, $p$ value $\leq 0.05$ that was calculated by multiple $t$ test and one-way ANOVA

IgG titer produced by chimeric HBc VLPs. The full length of allergen (rChe a 3), mixed with either alum or HBc VLPs, produced a higher titer of blocking IgG than the C-terminal half of allergen (C. Che a 3). Likewise, there was no significant difference between the level of blocking $\operatorname{IgG}$ induced by $\mathrm{C}$. Che a 3 peptide when applied in combination with alum or $\mathrm{HBc}$ VLPs (Fig. 6).

\section{The ratio of $\operatorname{lgG} 1 / \operatorname{lgG} 2 \mathrm{a}$ antibodies reduced in mice immunized with chimeric HBc VLPs}

Reduction in IgG1/IgG2a ratio in mice is considered the deviation of the immune system towards a Th1 response. In comparison to mice immunized with rChe a 3 or $\mathrm{C}$. Che a 3 peptide (mixed with alum or HBc VLP), a reduction in $\mathrm{IgG} 1 / \mathrm{IgG} 2 \mathrm{a}$ ratio was observed in sera from mice immunized
Fig. 4 Chimeric VLPs produce the highest level of rChe a $3-$ specific IgG in mice. Comparison of rChe a 3-specific IgG Ab titer in mice immunized (five mice per group) with rChe a $3, \mathrm{C}$. Che a 3 , chimeric HBc VLPs, HBc VLPs, or PBS on days 14, 21, and 42. Symbol meaning: *, $p$ value $\leq$ 0.05 that was calculated by multiple $t$ test and one-way ANOVA

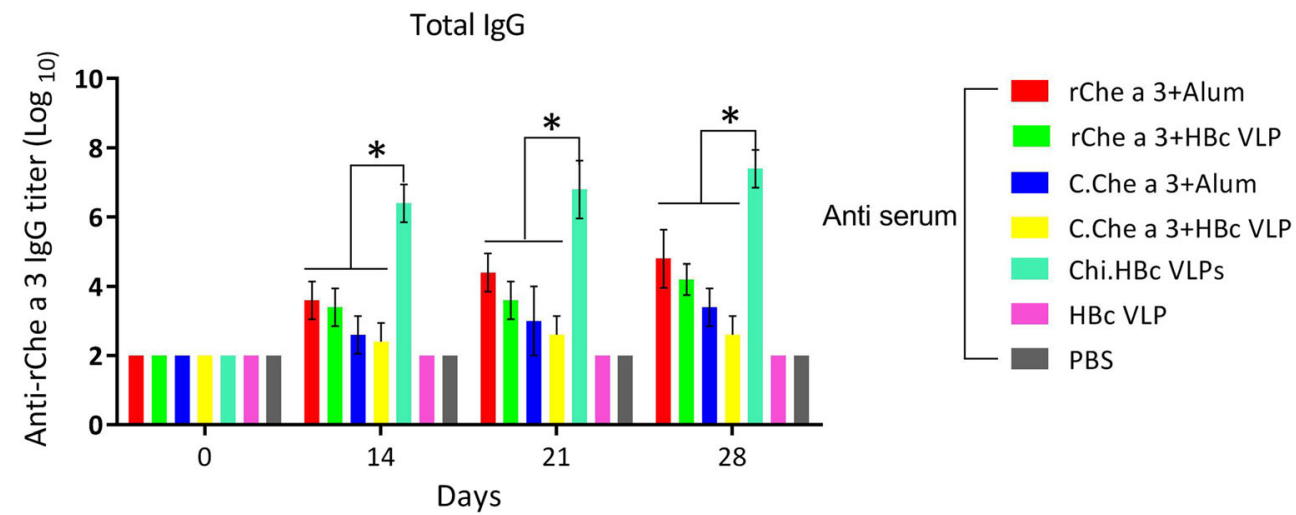




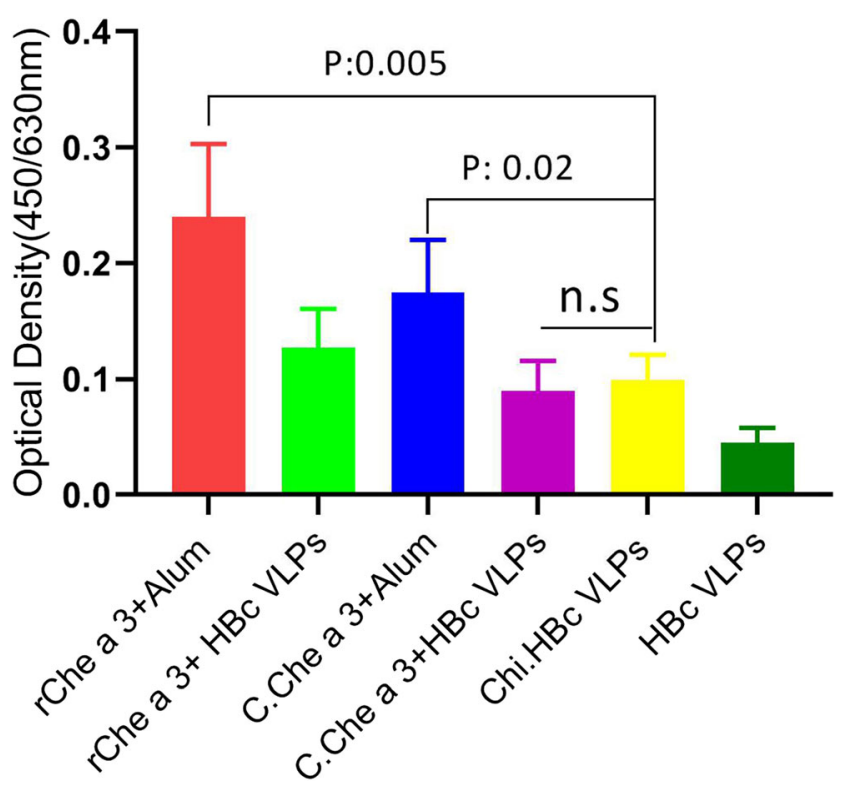

Fig. 5 Chimeric VLPs and C. Che a 3 produce the lowest level of rChe a 3 -specific IgE in mice. Forty-two days after first immunization, the level of rChe a 3-specific IgE antibody was evaluated in the sera of mice immunized (five mice per group) with rChe a 3, C. Che a 3, chimeric HBc VLPs, or HBc VLPs. The data represents the level of rChe a $3-$ specific IgE antibody (mean $\pm \mathrm{SD}$ ) in each group. $p$ values less than 0.05 were regarded as statistically significant.

with chimeric HBc VLPs. This Th1-biased immune response in mice immunized with chimeric HBc VLPs can be due to the presence of encapsidated nucleic acids in chimeric HBc VLPs.
RChe a 3 or C. Che a 3 peptide (mixed with alum or $\mathrm{HBc}$ VLPs) induced antibody response more toward IgG1 compared to IgG2a, suggesting that rChe a 3 or C. Che a 3 might induce a Th2-skewed immune response (Fig. 7).

Similar to antibody response, in vitro cytokine assay confirmed that only chimeric HBc VLPs could induce allergenspecific Th1 immune response. Splenocytes from mice immunized with rChe a 3, C. Che a3 peptide, chimeric HBc VLPs, or $\mathrm{HBc}$ VLPs were stimulated in vitro using rChe a 3 or $\mathrm{HBc}$ VLPs. Splenocytes from mice receiving chimeric HBc VLPs produced a higher level of IFN- $\gamma$ when stimulated with either HBc VLPs or rChe a 3, while splenocytes from mice that had received either $\mathrm{HBc}$ VLPs alone or in combination with allergen were capable of producing IFN- $\gamma$, only when their splenocytes were stimulated with HBc VLPs (no with rChe a 3 ) (Fig. 8).

\section{Discussion}

Virus-like particles induce immune responses via several ways that make them very attractive for use in allergy vaccines (Klimek et al. 2018; Li et al. 2011; Xu et al. 2014). The desired features of VLPs that are suitable for application in patients with allergic rhinitis include (i) efficient draining into the lymph nodes owing to these nanoparticle structures (30-100 $\mathrm{nm}$ ) can induce a robust humoral immune response and (ii)

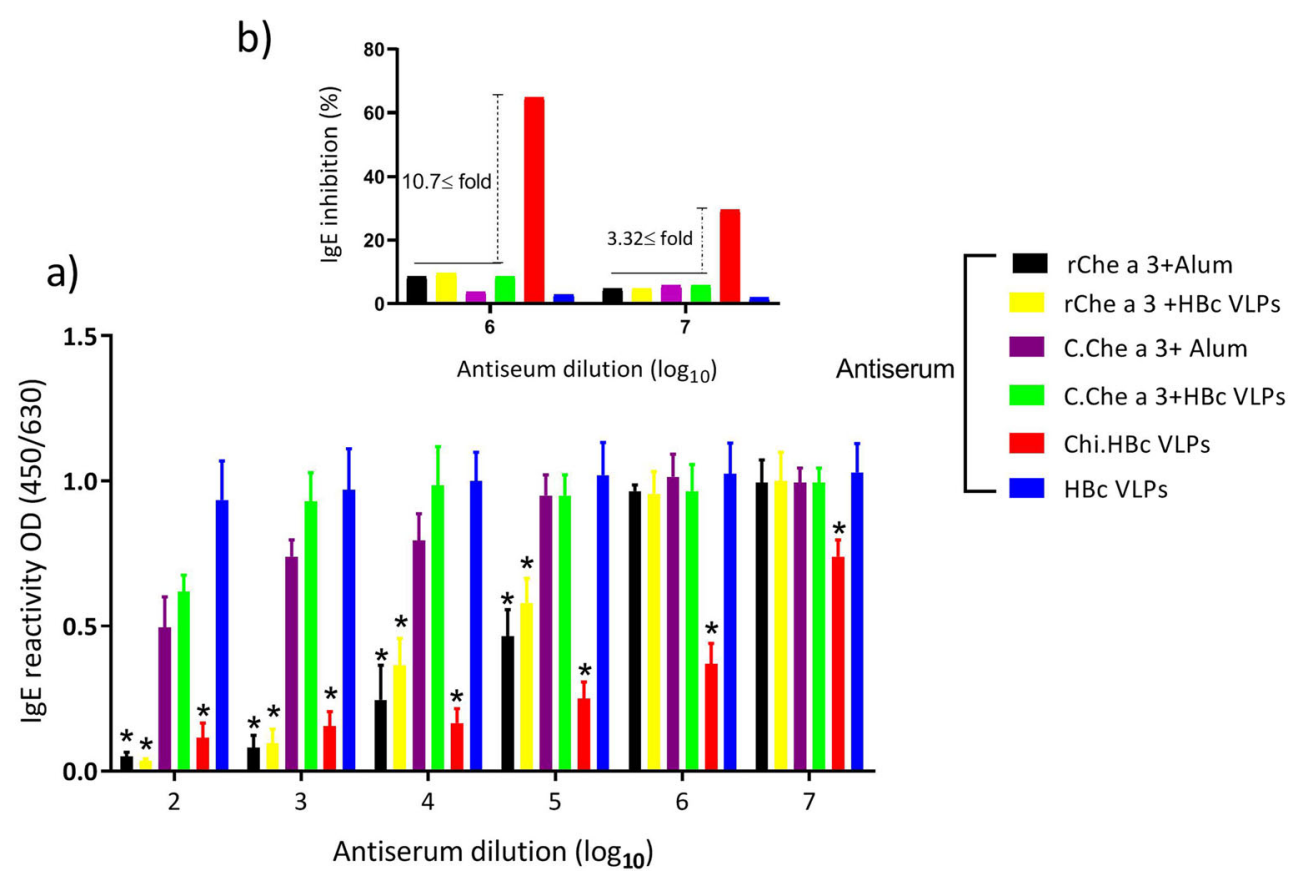

Fig. 6 Anti-chimeric HBc VLP IgG antibody produces the highest level of blocking IgG that inhibits allergic patients' IgE binding to rChe a 3. a The chart represents mean absorbance value for allergic patients' IgE reactivity to rChe a 3 that has been pre-incubated with various dilutions of mice sera. RChe a 3 was first incubated with various dilution sera from immunized mice within each group (five mice/group), and then probed

with pool sera from allergic patients' sera ( $n$ : 10). Mean \pm SD of each group was compared with HBc VLP group by one-way ANOVA. b Percent inhibition of allergic patients' IgE binding to rChe a 3 by sera forms immunized mice in two antiserum dilution. $p$ values less than 0.05 were regarded as statistically significant that were calculated by multiple $t$ test and one-way ANOVA 


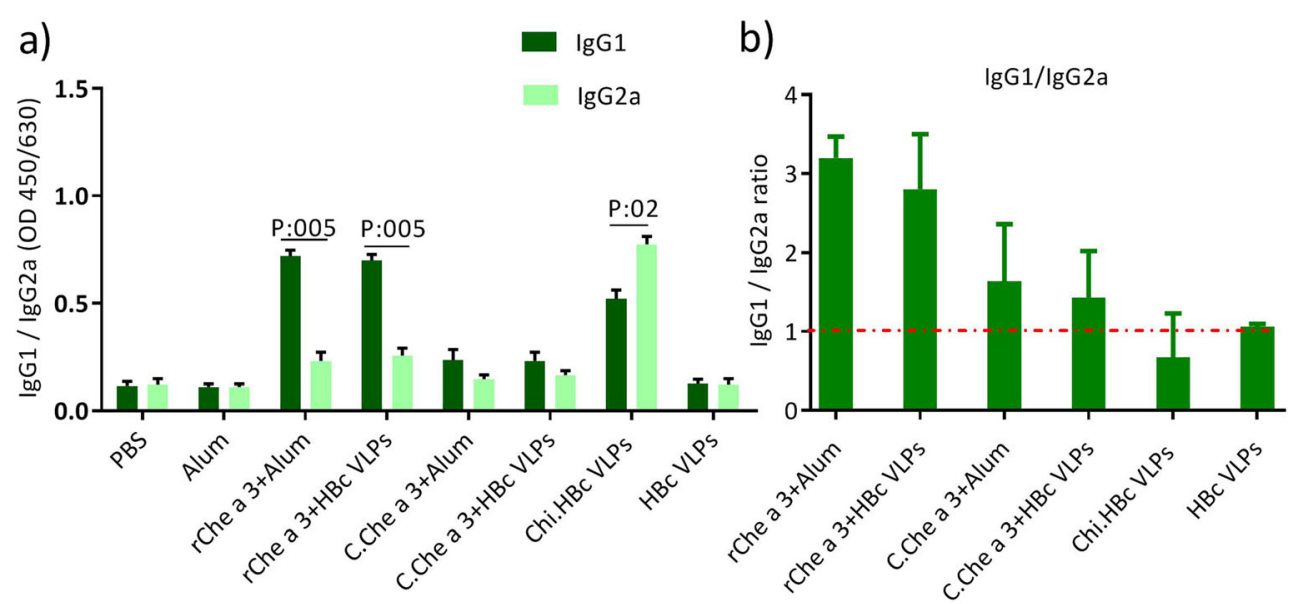

b)

Fig. 7 Chimeric HBc VLPs induce an antibody subclass response favor Th1 response. a The average of antibody subclass titer was measured by ELISA in eight groups (5 mice in each group); chimeric HBc VLPs produced a higher level of $\operatorname{IgG} 2$ a relative to other antigens. b Char represent mean $\pm \mathrm{SD}(n: 5)$ of rChe a 3 -specific $\operatorname{IgG1} / \mathrm{IgG} 2$ a ratio in

adjuvant properties of VLPs that induce a polarization toward Th-1 response (Klimek et al. 2018) that is known as a favorable response for allergy treatment (Kündig et al. 2015). It demonstrated that VLP is a safe and well-tolerated vaccine that is currently used as prophylactic vaccine against hepatitis $B$ virus and human papillomavirus. Similarly, the application of VLPs alone or simply mixed with HDM extract in clinical trial studies induces a positive effect on symptoms of allergic rhinitis and asthma, owing to the adjuvant effect of VLPinduced Th1 response (Kündig et al. 2015). Therefore, HBc VLP can be used as safe, non-allergenic therapeutic treatment platform using allergens and allergen derivatives to induce protective immune responses against allergen in allergyrelated diseases (Klimek et al. 2018; Kündig et al. 2015; Siskind et al. 1966).

Studies have previously established that the hypoallergenicity and immunogenicity are two important issues for immunotherapy (Himly et al. 2012; Kulis et al. 2012); hence, in this study, we each group. Mean $\pm \mathrm{SD}$ (IgG1/IgG2a ratio) of mice immunized with chimeric HBc VLPs was compared with other groups using multiple $t$ tests, one per row. $p$ values less than 0.05 were regarded as statistically significant that were calculated by multiple $t$ test and one-way ANOVA

designed, generated, and characterized the hypoallergenic $\mathrm{HBc}$ VLPs presenting allergen-derived peptide. Genetic engineering was employed to insert C-terminal half of Che a 3 (C. Che a 3) into the MIR of $\mathrm{HBc}$ antigen and displayed $\mathrm{C}$. Che a 3 in a repetitive fashion on the surface of $\mathrm{HBc}$ VLPs. Similar to $\mathrm{HBc}$ protein, chimeric HBc VLPs retain the self-assembly property and VLP formation when expressed in E. coli expression system, so prokaryotic expression systems can be used for chimeric $\mathrm{HBc}$ VLP-producing systems. Severe allergic reactions, including anaphylaxis, which is life-threatening, are important concerns of allergen-specific immunotherapy that may limit wide clinical use of AIT (Burks et al. 2013; Valenta 2002). In this respect, ELISA findings demonstrated a strong reduction in the IgE reactivity of $\mathrm{C}$. Che a 3 and chimeric HBc VLPs compared with rChe a 3 allergen. The reduced $\operatorname{IgE}$ reactivity of $C$. Che a 3 may be due to the disruption of three-dimensional structure of Che a 3 , because previous studies demonstrated that the IgE reactivity of two EF-hand calcium-binding allergens (i.e., parvalbumin and

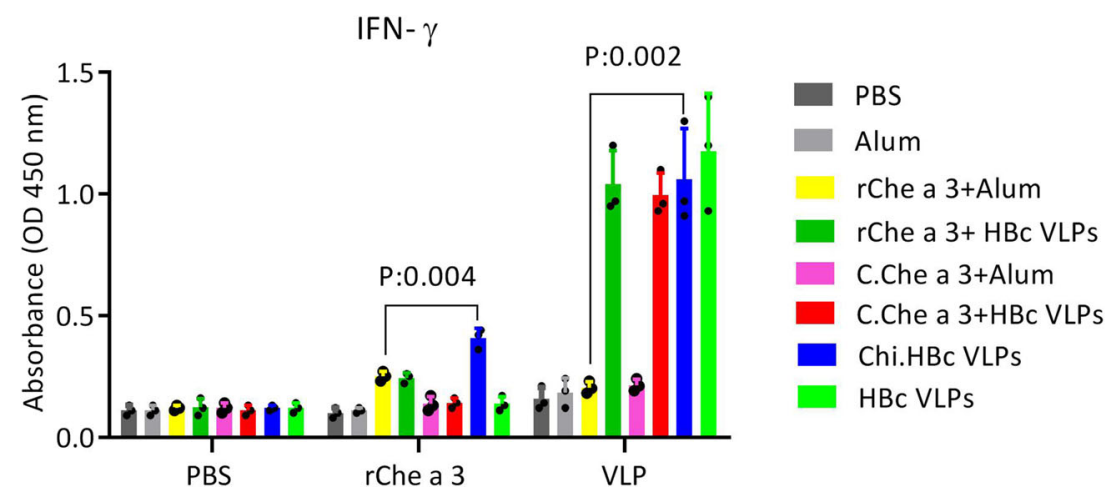

Fig. 8 Utilization of VLPs as platform induces a robust IFN-g response. Splenocytes of mice immunized with HBc VLPs alone or HBc VLP mixed with allergen induced a high level of IFN-g when only stimulated with HBc VLPs (no with rChe a 3), while splenocytes of

mice immunized with chimeric HBc VLPs produced high IFN-g when stimulated with either HBc VLPs or rChe a 3. $p$ values less than 0.05 were regarded as statistically significant that were calculated by multiple $t$ test and one-way ANOVA 
polcalcins) depends on their three-dimensional structure (Mohammadi et al. 2017; Swoboda et al. 2007; Westritschnig et al. 2004). These studies indicated that a disruption or alteration in the three-dimensional structures of two EF-hand calcium-binding allergens, by mutations in the calcium-binding site or fragmentation, led to the generation of a hypoallergenic variant (Mohammadi et al. 2017; Swoboda et al. 2007; Westritschnig et al. 2004). Consistent with these results, the basophil activation test demonstrated that chimeric HBc VLP and C. Che a 3 peptide at same the level exhibited very low basophil degranulationtriggering ability compared to that triggered by rChe a 3 . In agreement with this result, it has been demonstrated that repetitive displaying of allergen on the surface of VLPs, by chemical conjugation, led to loss of its basophil degranulation-triggering ability (Engeroff et al. 2018).

Inducing a robust and long-lasting antibody response (humoral immunity) and T helper cell (cellular immunity) is crucial to a successful immunotherapy (Klimek et al. 2013; Klimek et al. 2011). Evaluation of quantity and quality of the induced antibody response in mice revealed that a physical association between the allergen derivative (C. Che a3) and HBc VLPs (chimeric HBc VLP) is required for producing allergen-specific IgG2a antibody and a Th1 response. Thus, a single immunization with chimeric $\mathrm{HBc}$ VLPs induced a strong IgG response against rChe a 3 in comparison to those induced by allergen or its derivatives mixed with either HBc VLPs or alum. The reduced ratio of allergen-specific IgG1/IgG2a in mice immunized with chimeric HBc VLPs compared with that of immunized with rChe a 3 mixed with VLPs confirmed the induction of an allergen-specific Th1 response. This finding suggests that when allergen-derived peptide is physically linked to HBc VLPs, allergen-specific B cell simultaneously takes up both allergen-derived peptide and HBc VLPs. This may be the reason for the strong antibody induced by chimeric $\mathrm{HBc}$ VLPs compared to when the allergen is simply mixed with HBc VLPs that describe hapten-carrier and adjuvant effect of VLPs on antigen-presenting cells (i.e. ,B cells) (Siskind et al. 1966). In agreement with this finding, Gomes et al. demonstrated that physical association of antigen, VLPs and adjuvant are very crucial for B cell response (Gomes et al. 2017). Furthermore, the presentation of allergen derivatives on the surface of VLPs in a repetitive fashion enhances cross-linking of BCR those results in inducing a strong humoral immune response (Gomes et al. 2017). Schmitz et al. created high immunogenic and protective treatment against cat allergy by chemical coupling of major cat allergen Fel d1 to bacteriophage $\mathrm{Q} \beta$-derived virus-like particles which induced a protective and robust IgG response after a few injections. This ability is due to the incorporation of RNA into VLP during production of $\mathrm{Q} \beta$ derived VLPs in E. coli (Schmitz et al. 2009). However, coupling of antigen to VLPs by chemical coupling often leads to a lower density of the target epitope on the surface of VLP, as also, chemical coupling of complex antigens with several reactive sites to VLPs may complicate the correct coupling of antigen to VLPs which is crucial for optimal display of the epitope (Pattenden et al. 2005; Smith et al. 2013). It seems that the antigen displayed on VLP by genetic fusion may be an efficient strategy to overcome drawbacks of chemical coupling of antigen to VLPs. In this way, Arora et al. displayed envelope domain III (EDIII) from dengue viruses on the surface of HBc VLP and demonstrated that this chimeric particle was very immunogenic and induced high-titer anti-EDIII-2 protective IgG response (Arora et al. 2012).

Deviation of the immune response toward Th2 response is observed in allergic diseases. The purpose of allergy immunotherapy is to induce energy in allergen-specific Th2 or skew the immune response toward Th1 response (Smarr et al. 2013). Splenocytes obtained from mice were stimulated in vitro with allergen or $\mathrm{HBc}$ antigen to determine antigen-specific cytokine response. Splenocytes from mice immunized with either HBc VLPs alone (group HBc VLPs), chimeric HBc VLPs, or HBc VLPs mixed with allergen or its derivatives (groups: rChe a $3+$ VLPs, C. Che a $3+$ VLPs) produced high level of IFN- $\gamma$ in response to in vitro stimulation with $\mathrm{HBc}$ antigen compared with those immunized with rChe a 3 or $\mathrm{C}$. Che a 3 mixed with alum (groups: rChe a $3+$ alum, C. Che a $3+$ alum) or PBS group. However, in splenocytes of mice stimulated with rChe 3 , only those mice immunized with chimeric HBc VLPs produced significant secretion of IFN- $\gamma$. Production of IFN- $\gamma$ by splenocytes from mice immunized with chimeric HBc VLPs may be due to the existence of elevated allergen-specific $\mathrm{CD} 4^{+}$cells (Th1) that might have been induced by chimeric HBc VLPs in mice after immunization (Ebert and Jabri 2008). The encapsidated nucleic acids (RNA, DNA) into chimeric HBc VLPs during self-assembly of the coated proteins in E. coli act as agonists of TLR3/7/9 (Kanzler et al. 2007) and induce Th1-skewed immune response. Klimek et al. evaluated the efficiency of allergen-free QB-VLP vaccine for immunotherapy of patients with allergy to mites and demonstrated that VLPs containing TLR9 agonist reduced allergy symptom in allergic patients after the administration (Klimek et al. 2011). Sominskaya et al. indicated that the truncated $\mathrm{HBc}$ variant, lacking the nucleic acid-binding domains, can induce a dominant $\mathrm{Th} 2$ response compared to the full length of HBc VLP that contains encapsidated RNA (Sominskaya et al. 2013).

Although chimeric HBc VLP induces the highest level of rChe a 3-related IgG antibody, the lower potency of chimeric $\mathrm{HBc}$ VLP to produce IgE antibody in mice after immunization, even compared to $C$. Che a 3 mixed with alum, suggests that the chimeric HBc VLP can skew immune response toward Th1 response, resulting in a reduction of 
Th2-mediated IgE production. In contrast, the combination of allergen with alum, compared with HBc VLP, leads to the increase of rChe a 3-related IgE antibody, which may be due to Th2 response mediated by alum (Terhune and Deth 2018). These results suggest that HBc VLP is superior to alum in driving an immune response against allergic disease due to inducing a Th1 response. Prior studies demonstrated that aluminum adjuvants contribute to the ongoing development of the risk factors of allergies (Johnson-Weaver et al. 2018; Terhune and Deth 2018).

Taken together, antibody and cytokine assays revealed that the application of VLPs in combination with allergen (either linked or simply mixed) induced HBc VLP-specific Th1skewed immune response that had positive effect on symptoms of allergic rhinitis (Kündig et al. 2015). However, chimeric $\mathrm{HBc}$ VLPs, in contrast to other antigen formulations, not only induce an allergen-specific Th1-biased immune response but also produce high allergen-specific antibody response (especially IgG2a antibody) that can block an allergic patient's IgE binding to rChe a 3 and subsequently inhibit allergen-induced systemic basophil degranulation (Schmitz et al. 2009). Another therapeutic effect of allergen-specific IgG antibody includes the inhibition of IgE-mediated allergen exposure by dendritic cells and reduction of allergen-specific Th2 cells and IgE response (Sharquie et al. 2013; Valenta et al. 2009).

The main drawback of previous strategies to reduce allergenicity and create hypoallergenic forms of allergens (mutation, deletion, or inversion in the deduced amino acid sequence of allergens) is to disrupt and delete Th cell epitopes required for induction of an immune response. In other words, these epitopes determine immunogenicity (Alexander et al. 2005; Campana et al. 2014; Oldfield et al. 2001); therefore, the conjugation or fusion of allergen derivatives to a highly immunogenic carrier and rich in Th cell epitopes like HBc VLP can overcome this problem. In some studies, $\mathrm{CpG}$ motifs were used as adjuvant (Salem 2014; Senti et al. 2009) to increase the Th1 response against an allergen, but it has been demonstrated that free CpGs can induce splenomegaly after immunization compared to packaged CpG (Storni et al. 2004). For the first time, we studied the efficiency of VLP from hepatitis B core antigen ( $\mathrm{HBc}$ ) as a vaccine platform for the presentation of hypoallergenic allergen-derived peptides to the immune system. In this study, we specifically wanted to compare the allergenspecific immune response of mice receiving chimeric $\mathrm{HBc}$ VLP or allergen mixed with either HBc VLP or alum. As the mouse responses to HBc VLP are highly characterized, we included different combinations or individual treatments. It is important to note that the combination of HBc VLP + alum was not included in our study and may reduce the signal to background ratio of the immunoglobulin measurements; it does not affect the differences seen between the treatment groups. We believe that the treatment with chimeric $\mathrm{HBc}$ VLP has advantages, including the production of high level of allergen-specific IgG antibody and also induction of allergen-specific Th1 response when allergen simply mixed with HBc VLPs or alum. Further research is needed to evaluate the protective effects induced by chimeric $\mathrm{HBc}$ VLP in allergic mice models, and also determine allergenicity of chimeric HBc VLP in vivo and in vitro by a skin prick test and basophil activation test (BAT), respectively. Given that tradiational allergy immunotherapy has several drawbacks such as several shots over a long time due to the low immunogenicity, risk of anaphylaxis, and sometimes the lack of a curative effect, hence, we described strategies that removed drawbacks related to allergy shots and also improved humoral and cellular immune responses suitable for allergic rhinitis. Furthermore, it revealed that a physical linkage of allergen derivatives to HBc VLPs (not simply mixing allergen with HBc VLPs or alum) might provoke an efficient immune response that favored a successful allergy treatment.

Supplementary Information The online version contains supplementary material available at https://doi.org/10.1007/s00253-020-11012-0.

Authors' contributions MM, IN, and SJM conceived and designed research. MZ, AB, NM, PD, JA, SH, Kh H, and FO conducted experiments. $\mathrm{MM}, \mathrm{SJM}$, and SA contributed new reagents or analytical tools. AM and GR analyzed data. MM and SJM wrote the manuscript. All authors read and approved the manuscript.

Funding The Bushehr University of Medical Sciences provided this work a research budget. This study is the MS thesis of the first author and was supported by a research grant (code: 1218) from Bushehr University of Medical Sciences.

Data availability The authors confirm that the data supporting the findings of this study are available within the manuscript.

\section{Compliance with ethical standards}

Conflict of interest The authors declare that they have no conflicts of interest.

Ethical approval In case animals: All animal dealings in this study were performed under protocol approved by the Animal Care and Use Committee of Bushehr University of Medical Sciences-Iran (Permit number: IR.BPUMS.REC.1397.011). The animal procedures were in accordance with the Specific National Ethical Guidelines for Biomedical Research issued by the Research and Technology Deputy of Ministry of Health and Medicinal Education (MOHME) of Iran (issued in 2005).

In case human: All procedures performed in studies involving human participants were in accordance with the ethical standards of the Ethics Committee, Bushehr University of Medical Sciences with the 1964 Helsinki declaration and its later amendments or comparable ethical standards.

Statement of informed consent Informed consent was obtained from all individual participants included in the study. 


\section{References}

Ai C, Zhang Q, Ding J, Ren C, Wang G, Liu X, Tian F, Zhao J, Zhang H, Chen YQ, Chen W (2015) Suppression of dust mite allergy by mucosal delivery of a hypoallergenic derivative in a mouse model. Appl Microbiol Biotechnol 99(10):4309-4319

Alexander C, Tarzi M, Larche M, Kay A (2005) The effect of Fel d 1derived T-cell peptides on upper and lower airway outcome measurements in cat-allergic subjects. Allergy 60(10):1269-1274

Anzaghe M, Schülke S, Scheurer S (2018) Virus-like particles as carrier systems to enhance immunomodulation in allergen immunotherapy. Curr Allergy Asthma Rep 18(12):71

Arora U, Tyagi P, Swaminathan S, Khanna N (2012) Chimeric Hepatitis $\mathrm{B}$ core antigen virus-like particles displaying the envelope domain III of dengue virus type 2. J Nanobiotechnol 10(1):30

Bannon GA, Cockrell G, Connaughton C, West CM, Helm R, Stanley JS, King N, Rabjohn P, Sampson HA, Burks AW (2001) Engineering, characterization and in vitro efficacy of the major peanut allergens for use in immunotherapy. Int Arch Allergy Immunol 124(1-3):70 72

Barderas R, Villaba M, Batanero E, Pascual CY, Rodríguez R (2003) Role of profilin and polcalcin in chenopod pollen allergy. Allergy Clin Immunol 111(5):1132-1133

Beeh K-M, Kanniess F, Wagner F, Schilder C, Naudts I, HammannHaenni A, Willers J, Stocker H, Mueller P, Bachmann MF (2013) The novel TLR-9 agonist QbG10 shows clinical efficacy in persistent allergic asthma. J Allergy Clin Immunol 131(3):866-874

Burks AW, Calderon MA, Casale T, Cox L, Demoly P, Jutel M, Nelson H, Akdis CA (2013) Update on allergy immunotherapy: American Academy of Allergy, Asthma \& Immunology/European Academy of Allergy and Clinical Immunology/PRACTALL consensus report. J Allergy Clin Immunol 131(5):1288-1296. e3

Campana R, Valenta R, Vrtala S, Swoboda I, Focke-Tejkl M, Gieras A, Spitzauer S, Valent P, Blatt K, Linhart B (2014) Hypallergenic mosaic antigens and methods of making same. Google Patents

Care IoLARCo, Animals UoL, Resources NIoHDoR (1985) Guide for the care and use of laboratory animals. National Academies, Washington, DC

Curin M, Khaitov M, Karaulov A, Namazova-Baranova L, Campana R, Garib V, Valenta R (2018) Next-generation of allergen-specific immunotherapies: molecular approaches. Curr Allergy Asthma Rep 18(7):39

Ebert EC, Jabri B (2008) Massive interleukin-12-induced interferon- $\gamma$ production by interleukin-15-stimulated lamina propria lymphocytes followed by down-regulation of the interleukin-12 receptor. J Immunol 124(4):453-460

Engeroff P, Caviezel F, Storni F, Thoms F, Vogel M, Bachmann MF (2018) Allergens displayed on virus-like particles are highly immunogenic but fail to activate human mast cells. Allergy 73(2):341349

Ghasemi A, Falak R, Mohamadi M, June Maleki S, Assarezadegan M-A, Jafary M (2020) Incorporation of T-cell epitopes from tetanus and diphtheria toxoids into in-silico-designed hypoallergenic vaccine may enhance the protective immune response against allergens. Iran J Basic Med Sci 23(5):636-644

Gomes AC, Flace A, Saudan P, Zabel F, Cabral-Miranda G, Turabi AE, Manolova V, Bachmann MF (2017) Adjusted particle size eliminates the need of linkage of antigen and adjuvants for appropriated $\mathrm{T}$ cell responses in virus-like particle-based vaccines. Front Immunol 8:226

Guo J, Zhou A, Sun X, Sha W, Ai K, Pan G, Zhou C, Zhou H, Cong H, He S (2019) Immunogenicity of a virus-like-particle vaccine containing multiple antigenic epitopes of Toxoplasma gondii against acute and chronic Toxoplasmosis in mice. Front Immunol 10:592
Hauser M, Roulias A, Ferreira F, Egger M (2010) Panallergens and their impact on the allergic patient. Allergy, Asthma Clin Immunol 6(1): $1-14$

Hedlin G, Graff-Lonnevig V, Heilborn H, Lilja G, Norrlind K, Pegelow K, Sundin B, Lowenstein H (1991) Immunotherapy with cat-and dog-dander extracts: V. Effects of 3 years of treatment. J Allergy Clin Immunol 87(5):955-964

Himly M, Wallner M, Zaborsky N, Hauser M, Gadermaier G, Harrer A, Ferreira F (2012) Physicochemical characterization of recombinant allergens and hypoallergenic variants. Arb Paul Ehrlich Inst Bundesinstitut Impfstoffe Biomed Arzneim Langen Hess 97:101105

Huber J, Ramos H, Gill M, Farrar J (2010) Type I interferon reverses human Th2 commitment and stability by repressing GATA3. j. Immunol 185(2):813-817

Johnson-Weaver BT, McRitchie S, Mercier KA, Pathmasiri W, Sumner SJ, Chan C, Germolec D, Kulis M, Burks AW, Staats HF (2018) Effect of endotoxin and alum adjuvant vaccine on peanut allergy. Allergy Clin Immunol 141(2):791-794. e8

Kanzler H, Barrat FJ, Hessel EM, Coffman RL (2007) Therapeutic targeting of innate immunity with Toll-like receptor agonists and antagonists. Nat Med 13(5):552-559

Klimek L, Willers J, Hammann-Haenni A, Pfaar O, Stocker H, Mueller P, Renner W, Bachmann M (2011) Assessment of clinical efficacy of CYT003-QbG10 in patients with allergic rhinoconjunctivitis: a phase IIb study. Clin Exp Allergy 41(9):1305-1312

Klimek L, Schendzielorz P, Mueller P, Saudan P, Willers J (2013) Immunotherapy of allergic rhinitis: new therapeutic opportunities with virus-like particles filled with CpG motifs. Am J Rhinol Allergy 27(3):206-212

Klimek L, Kündig T, Kramer MF, Guethoff S, Jensen-Jarolim E, Schmidt-Weber CB, Palomares O, Mohsen MO, Jakob T, Bachmann M (2018) Virus-like particles (VLP) in prophylaxis and immunotherapy of allergic diseases. Allergo J Int 27(8):245-255

Komlósi ZI, Kovács N, Sokolowska M, van de Veen W, Akdis M, Akdis CA (2020) Mechanisms of subcutaneous and sublingual aeroallergen immunotherapy: what is new? Immunol Allergy Clin 40(1):1-14

Kulis M, MacQueen I, Li Y, Guo R, Zhong X-P, Burks AW (2012) Pepsinized cashew proteins are hypoallergenic and immunogenic and provide effective immunotherapy in mice with cashew allergy. J Allergy Clin Immunol 130(3):716-723

Kündig TM, Senti G, Schnetzler G, Wolf C, Vavricka BMP, Fulurija A, Hennecke F, Sladko K, Jennings GT, Bachmann MF (2006) Der p 1 peptide on virus-like particles is safe and highly immunogenic in healthy adults. J Allergy Clin Immunol 117(6):1470-1476

Kündig TM, Klimek L, Schendzielorz P, Renner WA, Senti G, Bachmann MF (2015) Is the allergen really needed in allergy immunotherapy? Curr Treat Options Allergy 2(1):72-82

Ledesma A, Barderas R, Westritschnig K, Quiralte J, Pascual C, Valenta R, Villalba M, Rodriguez R (2006) A comparative analysis of the cross-reactivity in the polcalcin family including Syr v 3, a new member from lilac pollen. Allergy 61(4):477-484

Li JJ, Zhao F, Li J (2011) Polyrotaxanes for applications in life science and biotechnology. Appl Microbiol Biotechnol 90(2):427-443

Linhart B, Valenta R (2005) Molecular design of allergy vaccines. Curr Opin Immunol 17(6):646-655

Mohamadi M, Falak R, Mokhtarian K, Khoramizadeh MR, Sadroddiny E, Kardar GA (2016) Identification and characterization of main allergic proteins in cooked wolf herring fish. Iran J Allergy Asthma Immunol 15(5):363-371

Mohammadi M, Mokhtarian K, Kardar GA, Farrokhi S, Sadroddiny E, Khorramizadeh MR, Falak R (2017) Expression of recombinant parvalbumin from wolf-herring fish and determination of its IgEbinding capability. Food Agric Immunol 28(4):573-585 
Mohan T, Berman Z, Luo Y, Wang C, Wang S, Compans RW, Wang BZ (2017) Chimeric virus-like particles containing influenza HA antigen and GPI-CCL28 induce long-lasting mucosal immunity against $H 3 N 2$ viruses. Sci Rep 7:40226

Mohsen MO, Speiser DE, Knuth A, Bachmann MF (2020) Virus-like particles for vaccination against cancer. Wiley Interdiscip Rev Nanomed Nanobiotechnol 12(1):e1579

Narisety SD, Keet CA (2012) Sublingual vs oral immunotherapy for food allergy. Drugs 72(15):1977-1989

Nouri HR, Varasteh A, Vahedi F, Chamani J, Afsharzadeh D, Sankian M (2012) Constructing a hybrid molecule with low capacity of IgE binding from Chenopodium album pollen allergens. Immunol Lett 144(1-2):67-77

Oldfield WL, Kay AB, Larché M (2001) Allergen-derived T cell peptideinduced late asthmatic reactions precede the induction of antigenspecific hyporesponsiveness in atopic allergic asthmatic subjects. J Immunol 167(3):1734-1739

Oliveira GA, Wetzel K, Calvo-Calle JM, Nussenzweig R, Schmidt A, Birkett A, Dubovsky F, Tierney E, Gleiter CH, Boehmer G (2005) Safety and enhanced immunogenicity of a hepatitis B core particle Plasmodium falciparum malaria vaccine formulated in adjuvant Montanide ISA 720 in a phase I trial. Infect Immun 73(6):35873597

Oliveira M, Amorim MI, Ferreira E, Delgado L, Abreu I (2010) Main airborne Ascomycota spores: characterization by culture, spore morphology, ribosomal DNA sequences and enzymatic analysis. Appl Microbiol Biotechnol 86(4):1171-1181

Pajno GB, Cox L, Caminiti L, Ramistella V, Crisafulli G (2014) Oral immunotherapy for treatment of immunoglobulin E-mediated food allergy: the transition to clinical practice. Pediatr Allergy Immunol Pulmonol 27(2):42-50

Pattenden LK, Middelberg AP, Niebert M, Lipin DI (2005) Towards the preparative and large-scale precision manufacture of virus-like particles. Trends Biotechnol 23(10):523-529

Peyret H, Gehin A, Thuenemann EC, Blond D, El Turabi A, Beales L, Clarke D, Gilbert RJ, Fry EE, Stuart DI, Holmes K, Stonehouse NJ, Whelan M, Rosenberg W, Lomonossoff GP, Rowlands DJ (2015) Tandem fusion of hepatitis B core antigen allows assembly of viruslike particles in bacteria and plants with enhanced capacity to accommodate foreign proteins. PLoS One 10(4):e0120751

Pumpens P, Grens E (2001) HBV core particles as a carrier for B cell/T cell epitopes. Intervirology 44(2-3):98-114

Pumpens P, Borisova G, Crowther R, Grens E (1995) Hepatitis B virus core particles as epitope carriers. Intervirology 38(1-2):63-74

Ren C, Zhang Q, Wang G, Ai C, Hu M, Liu X, Tian F, Zhao J, Chen Y, Wang M, Zhang H, Chen W (2014) Modulation of peanut-induced allergic immune responses by oral lactic acid bacteria-based vaccines in mice. Appl Microbiol Biotechnol 98(14):6353-6364

Salem AK (2014) A promising CpG adjuvant-loaded nanoparticle-based vaccine for treatment of dust mite allergies. Immunotherapy $6(11)$ : $1161-1163$

Sanz M, Sanchez G, Gamboa P, Vila L, Uasuf C, Chazot M, Dieguez I, De Weck A (2001) Allergen-induced basophil activation: CD63 cell expression detected by flow cytometry in patients allergic to Dermatophagoides pteronyssinus and Lolium perenne. Clin Exp Allergy 31(7):1007-1013

Schmitz N, Dietmeier K, Bauer M, Maudrich M, Utzinger S, Muntwiler S, Saudan P, Bachmann MF (2009) Displaying Fel d1 on virus-like particles prevents reactogenicity despite greatly enhanced immunogenicity: a novel therapy for cat allergy. J Exp Med 206(9):19411955

Schödel F, Kelly S, Tinge S, Hopkins S, Peterson D, Milich D, Curtiss III R (1996) Hybrid Hepatitis B virus core antigen as a vaccine carrier moiety. Novel strategies in the design and production of vaccines. Springer, pp 15-21
Senti G, Johansen P, Haug S, Bull C, Gottschaller C, Müller P, Pfister T, Maurer P, Bachmann M, Graf N (2009) Use of a-type CpG oligodeoxynucleotides as an adjuvant in allergen-specific immunotherapy in humans: a phase I/IIa clinical trial. Clin Exp Allergy 39(4):562-570

Sharquie IK, Al-Ghouleh A, Fitton P, Clark MR, Armour KL, Sewell HF, Shakib F, Ghaemmaghami AM (2013) An investigation into IgEfacilitated allergen recognition and presentation by human dendritic cells. BMC Immunol 14(1):54

Siskind GW, Paul WE, Benacerraf B (1966) Studies on the effect of the carrier molecule on antihapten antibody synthesis I. Effect of carrier on the nature of the antibody synthesized. J Exp Med 123(4):673688

Smarr CB, Bryce PJ, Miller SD (2013) Antigen-specific tolerance in immunotherapy of Th2-associated allergic diseases. Crit Rev Immunol 33(5):389-414

Smith MT, Hawes AK, Bundy BC (2013) Reengineering viruses and virus-like particles through chemical functionalization strategies. Curr Opin Biotechnol 24(4):620-626

Sominskaya I, Skrastina D, Petrovskis I, Dishlers A, Berza I, Mihailova M, Jansons J, Akopjana I, Stahovska I, Dreilina D (2013) A VLP library of C-terminally truncated Hepatitis B core proteins: correlation of RNA encapsidation with a Th1/Th2 switch in the immune responses of mice. PLoS One 8(9):e75938

Storni T, Ruedl C, Schwarz K, Schwendener RA, Renner WA, Bachmann MF (2004) Nonmethylated CG motifs packaged into virus-like particles induce protective cytotoxic $\mathrm{T}$ cell responses in the absence of systemic side effects. J Immunol 172(3):1777-1785

Storni F, Zeltins A, Balke I, Heath MD, Kramer MF, Skinner MA, Zha L, Roesti E, Engeroff P, Muri L (2020) Vaccine against peanut allergy based on engineered virus-like particles displaying single major peanut allergens. J Allergy Clin Immunol 145(4):1240-1253. e3

Swoboda I, Bugajska-Schretter A, Verdino P, Keller W, Sperr WR, Valent P, Valenta R, Spitzauer S (2002) Recombinant carp parvalbumin, the major cross-reactive fish allergen: a tool for diagnosis and therapy of fish allergy. J Immunol 168(9):4576-4584

Swoboda I, Bugajska-Schretter A, Linhart B, Verdino P, Keller W, Schulmeister U, Sperr WR, Valent P, Peltre G, Quirce S (2007) A recombinant hypoallergenic parvalbumin mutant for immunotherapy of IgE-mediated fish allergy. J Immunol 178(10):6290-6296

Terhune T, Deth R (2018) Aluminum adjuvant-containing vaccines in the context of the hygiene hypothesis: a risk factor for eosinophilia and allergy in a genetically susceptible subpopulation? Int J Environ Res Public Health 15(5):901

Tinghino R, Twardosz A, Barletta B, Puggioni EM, Iacovacci P, Butteroni C, Afferni C, Mari A, Hayek B, Di Felice G (2002) Molecular, structural, and immunologic relationships between different families of recombinant calcium-binding pollen allergens. $\mathrm{J}$ Allergy Clin Immunol 109(2):314-320

Valenta R, Kraft D (2002) From allergen structure to new forms of allergen-specific immunotherapy. Curr Opin Immunol 14(6):718727

Valenta R, Ferreira F, Focke-Tejkl M, Linhart B, Niederberger V, Swoboda I, Vrtala S (2009) From allergen genes to allergy vaccines. Annu Rev Immunol 28:211-241

Verdino P, Barderas R, Villalba M, Westritschnig K, Valenta R, Rodriguez R, Keller W (2008) Three-dimensional structure of the cross-reactive pollen allergen Che a 3 : visualizing cross-reactivity on the molecular surfaces of weed, grass, and tree pollen allergens. J Immunol 180(4):2313-2321

Wang W, Chen X, Xue C, Du Y, Lv L, Liu Q, Li X, Ma Y, Shen H, Cao Y (2012) Production and immunogenicity of chimeric virus-like particles containing porcine reproductive and respiratory syndrome virus GP5 protein. Vaccine 30(49):7072-7077

Westritschnig K, Focke M, Verdino P, Goessler W, Keller W, Twardosz A, Mari A, Horak F, Wiedermann U, Hartl A (2004) Generation of 
an allergy vaccine by disruption of the three-dimensional structure of the cross-reactive calcium-binding allergen, $\mathrm{Phl} \mathrm{p} 7$. J Immunol 172(9):5684-5692

Winther L, Arnved J, Malling HJ, Nolte H, Mosbech H (2006) Sideeffects of allergen-specific immunotherapy. A prospective multicentre study. Clin Exp Allergy 36(3):254-260

Xu J, Guo HC, Wei YQ, Dong H, Han SC, Ao D, Sun DH, Wang HM, Cao SZ, Sun SQ (2014) Self-assembly of virus-like particles of canine parvovirus capsid protein expressed from Escherichia coli and application as virus-like particle vaccine. Appl Microbiol Biotechnol 98(8):3529-3538. https://doi.org/10.1007/s00253-013$5485-6$

Publisher's note Springer Nature remains neutral with regard to jurisdictional claims in published maps and institutional affiliations.

\section{Affiliations}

Maryam Zamani Sani ${ }^{1} \cdot$ Afshar Bargahi $^{1} \cdot$ Niloofar Momenzadeh $^{2} \cdot$ Parva Dehghani $^{2} \cdot$ Maryam Vakili Moghadam $^{3} \cdot$ Soheila June Maleki ${ }^{4}$. Iraj Nabipour ${ }^{2}$. Afshin Shirkani ${ }^{5}$ - Javad Akhtari ${ }^{6} \cdot$ Khashayar Hesamizadeh $^{7}$. Sahel Heidari ${ }^{3}$. Fatemeh Omrani ${ }^{2} \cdot$ Samad Akbarzadeh $^{1} \cdot$ Mohsen Mohammadi $^{2}$ (B)

1 Department of Biochemistry, School of Medicine, Bushehr University of Medical Sciences, Bushehr, Iran

2 The Persian Gulf Marine Biotechnology Research Center, The Persian Gulf Biomedical Sciences Research Institute, Bushehr University of Medical Sciences, Moallem Street, Bushehr 7514633196, Iran

3 Department of Immunology, School of Medicine, Iran University of Medical Sciences, Tehran, Iran
4 Southern Regional Research Center, Agricultural Research Service, US Department of Agriculture, New Orleans, LA, USA

5 Allergy and Clinical Immunology Department, School of Medicine, Bushehr University of Medical Sciences, Bushehr, Iran

6 Toxoplasmosis Research Center, Department of Medical Nanotechnology, Faculty of Medicine, Mazandaran University of Medical Sciences, Sari, Iran

7 Department of Virology, Iran University of Medical Sciences, Tehran, Islamic Republic of Iran 